\title{
Willingness to Pay for the Maintenance of Green Infrastructure in Six Chinese Pilot Sponge Cities
}

\author{
Xiu-Juan Qiao ${ }^{1, *}$ (i) and Thomas B. Randrup ${ }^{2}$ (D) \\ 1 College of Landscape Architecture and Art, Northwest A\&F University, Xianyang 712100, China \\ 2 Department of Landscape Architecture, Planning and Management, Swedish University of Agricultural \\ Sciences, 23053 Alnarp, Sweden; thomas.randrup@slu.se \\ * Correspondence: qiaoxiujuan@hotmail.com
}

check for updates

Citation: Qiao, X.-J.; Randrup, T.B. Willingness to Pay for the

Maintenance of Green Infrastructure in Six Chinese Pilot Sponge Cities.

Water 2022, 14, 428. https: / /doi.org/ $10.3390 / \mathrm{w} 14030428$

Academic Editors: Maria Mimikou and Richard C. Smardon

Received: 8 January 2022

Accepted: 28 January 2022

Published: 29 January 2022

Publisher's Note: MDPI stays neutral with regard to jurisdictional claims in published maps and institutional affiliations.

Copyright: (C) 2022 by the authors. Licensee MDPI, Basel, Switzerland. This article is an open access article distributed under the terms and conditions of the Creative Commons Attribution (CC BY) license (https:// creativecommons.org/licenses/by/ $4.0 /)$.

\begin{abstract}
Due to the increasingly devastating impact of pluvial flooding on human beings' lives and properties in cities, the use of green infrastructure to manage stormwater onsite is becoming more popular worldwide. The maintenance of green infrastructure to ensure its function has become one of the most pressing tasks facing policy makers. However, there is limited research regarding the willingness to pay the stormwater fee as a form of maintenance funding. This study utilized contingent valuation data obtained from a survey of 1101 respondents living in six pilot sponge cities in China to estimate the willingness to pay for the green infrastructure maintenance. The findings indicated that two-thirds of all respondents were willing to pay, $17 \%$ would like to pay around 6-10 RMB/month (0.95-1.59 US dollars/month), and 17.8\% would like to pay more than $20 \mathrm{RMB} /$ month (3.2 US dollars/month). The educational level and age of the respondents were significant determinants of the probability of willingness to pay and the amount they would like to pay. Knowledge of the concept of sponge cities was another significant influencing factor for the willingness to pay, but it did not influence the amount of payment. The findings could help policy makers make better strategies regarding the maintenance of green infrastructure and its costs.
\end{abstract}

Keywords: stormwater fee; maintenance funding; willingness to pay; green infrastructure; sponge cities

\section{Introduction}

Continuous urbanization and global climate change have created great challenges for the piped-drainage systems, causing cities around the world to suffer from waterlogging or problems related to pluvial flooding [1-3]. The concept of green infrastructure (GI) stands for interconnected networks of all kinds of green spaces [4], including raingardens, bioswales, detention or retention ponds, etc. GI is often used to tackle climate change impacts by favoring infiltration, reducing runoff volumes, and providing reliable and efficient adaptation measures [4-6]. GI in general has become an important method of reducing flood risk by mimicking the natural process to deal with stormwater onsite [7-9], and it helps to achieve both development and environmental protection [10].

It has been reported that maintenance is of significance for ensuring GI functions effectively [11-15]. In early 2008, it was reported that to keep wet ponds functioning, routine monitoring and regular sediment cleaning are necessary [16]. Asleson et al. (2009) found that 12 rain gardens in Minnesota, USA did not function due to a lack of maintenance [17]. After investigating 279 stormwater management facilities along highways in Prince George's County, Maryland, USA, Li (2015) reported that extensive maintenance was needed for these facilities [18]. Reyes et al. (2018) reported that infiltration trenches exhibited a decrease in pollutant reduction two years after their construction due to aging and lack of proper maintenance [19]. Even if regular maintenance and management are carried out, the effectiveness of GI (such as permeable paving and detention ponds) would be weakened over time [20]. 
However, lack of maintenance funding has become a common question in many countries in terms of water infrastructure [21,22]. It is reported that the maintenance cost of GI is high [1,23-25], which limits its wider implementation [1,26]. To ensure the normal operations of GI, a large amount of professional and technical personnel need to be engaged for its maintenance and management. It was reported that the maintenance fees associated with bioswales is one of the main concerns for the citizens of Portland, USA [10].

Similarly, the Chinese pilot sponge cities also suffered from a lack of maintenance funding [15,27]. In 2014, the Chinese government created the Sponge City Initiative [28], which aims to manage stormwater using a natural process of storing, infiltrating, and purifying stormwater [15]. In 2015, 16 cities were selected as pilot sponge cities, with another 14 cities selected in 2016. The pilot sponge cities constructed GI facilities in their demonstration zones (including parks, roads, communities, etc.). In 2019, all 30 pilot cities completed the construction of pilot projects. Currently, the piped-drainage systems are maintained by the municipal department in accordance with the Chinese national standard "Technical Regulations for Operation, Maintenance and Safety of Urban Drainage Pipes and Pumping Stations" (CJJ68-2016). However, no department is responsible for the maintenance of the sponge cities' GI facilities. Although many GI facilities were built more than five years ago, according to an official from the Sponge City Leader Office in Xi'Xian New Area, there was no maintenance implemented after the construction of sponge city facilities in the city. Based on site visits to several pilot sponge cities, we found that many GI facilities had broken or were choked with silt, especially the GI facilities built in old residential areas. The Chinese government provided extensive funding for the construction of pilot sponge cities, but no financial support has been given to the maintenance of these sponge city facilities.

Collecting stormwater fees has been suggested as a dedicated and stable source for covering the maintenance funding $[3,29,30]$, which has been done in Australia, Canada, Germany, and the United States [1,29-33]. Generally, stormwater management facilities rely on government funds, but the funds normally have restrictions on their use for stormwaterrelated activities [3]. Stormwater fee can be used for directly covering maintenance funding. In interviews with personnel from the Sponge City Leader Office in Xi'Xian New Area and Zhenjiang (pilot sponge cities in China), the possibility of collecting stormwater fees from residents as the source of GI maintenance funding was discussed, but no conclusion has yet been made.

Some researchers have conducted surveys on the willingness to pay (WTP) for the construction or implementation of green spaces [5,34-37]. For the Sponge City Initiative, studies on public preferences for urban stormwater management plans, policies, design, and creation of facilities have been conducted [38-41]. However, until now, only one research project has been reported to evaluate the public WTP for the life-cycle maintenance of sponge city facilities based on a survey of 453 samples in three pilot sponge cities in China [42]. In general, they found that most people $(76 \%)$ would like to pay for the maintenance fee. However, to make a suitable policy of GI maintenance, more opinions from the citizens are necessary. In addition, in 2021, the Chinese government announced a desire to "enhance urban flood control and drainage capabilities, and build sponge cities" in the outline of the 14th Five-Year Plan (2021-2025) [43]. Thus, in the future, a large amount of funds and resources will be invested in future sponge city construction. To ensure the effectiveness of sponge city construction and to avoid loss of investment, maintenance of GI needs to be a central concern. Thus, it is meaningful to study the public's WTP for the stormwater fees as GI maintenance funding and its influencing factors. This study will provide suggestions for how policy makers can make better strategies regarding the maintenance of GI and its costs. 


\section{Methodology}

\subsection{Data Collection}

By using of the contingent valuation method, one can use survey questionnaires to ask people to state their WTP preference in order to see improvements or avoid a decline in the quality or quantity of public goods, including environmental goods [37]. We used this method to investigate the public's perceptions on the maintenance of GI and their attitudes toward paying a maintenance fee. The method has been used in many similar studies $[1,3,21,37,42,44-47]$; Thus the method is well described and tested, but to our knowledge has not been applied in assessing willingness to pay for GI maintenance.

The survey questionnaire in this study consisted of four parts. First, the respondents were informed of the purpose of the study. Secondly, the respondents were asked to provide sociodemographic information, including gender, family's monthly income, job, age, and education level. In contingent valuation investigations, respondents' social and demographic features are frequently involved to test whether they have any effect on the public's WTP under different scenarios [42]. In the third part, the respondents' cognition toward sponge cities was investigated. If they reported knowledge of the concept of sponge cities, then they were asked to explain where and how they had obtained the information and their assessment of how the local sponge cities worked to ensure they had a full understanding of the concept. If they did not have previous knowledge of sponge cities, the survey staff would explain the sponge city concept briefly and show them pictures to explain how sponge city facilities work. Further, the respondents were asked if the residence areas where they live were rebuilt with sponge city facilities. In the fourth part, the respondents were asked whether they were willing to pay for the GI maintenance as well as the amount of money they would potentially be willing to pay.

The questionnaire-based survey was carried out through face-to-face interviews with citizens from six pilot sponge cities (Chongqing, Nanning, Pingxiang, Qingdao, Xi'Xian New Area, and Zhenjiang) from June to August 2021. The chosen case cities all represent the first batch of pilot sponge cities and are in different climate zones in China (Figure 1). All the cities were reported to have conducted relevant work on the construction of sponge cities. When conducting the questionnaires, we selected three kinds of places, specifically communities having built sponge city GI facilities, shopping malls in the city center, and local parks with sponge city GI facilities. Since income was reported as an influencing factor of WTP by many studies [25,44,46,48], the respondents under the age of 18 or with no income were not included. In addition, we avoided the respondents' who were renting apartments, considering that housing tenure may influence their WTP. We collected all the information from the questionnaires into an Excel sheet, and questionnaires without full information were not included. In total, we had 1101 effective respondents.

\subsection{Data Analysis}

\subsubsection{Binary Logistic Regression}

SPSS 24.0 was used to analyze the data. First, the frequencies and percentages were calculated in terms of (i) the respondents' sociodemographic information (including gender, age, educational level, and family's monthly income), (ii) whether or not the respondents had previous knowledge of the sponge city concept, (iii) whether their communities have sponge city facilities, (iv) the places (communities having built sponge city GI facilities, shopping malls in the city center, and local parks with sponge city GI facilities) where the questionnaires were conducted, (v) the case cities where the questionnaires were conducted, (vi) the WTP, and (vii) the amount respondents are willing to pay. Then, a bivariate correlation analysis was done between WTP and the variables of gender, age, education level, family's monthly income, previous knowledge of the sponge city concept, knowing whether the respondents' communities had built sponge city GI facilities, the respondents' geographical locations, as well as the pilot cities where the respondents conducted the questionnaires. Lastly, a binary-choice logistic model was used to analyze the influencing factors of WTP. The respondents' decision of whether to pay or not took the form of 
dichotomous variables, which could be solved using a cumulative probability distribution function, while a logistic fit model was used to analyze the survey data [37]. Therefore, the binary logistic model in SPSS 24.0 was used to analyze the probability of WTP and its correlated variates. The respondents' WTP was set in a binary form ( $\mathrm{YES}=1, \mathrm{NO}=0$ ). The WTP was set as a dependent variable and the recognized correlated influencing factors were set as independent variables. The data was analyzed with a $95 \%$ confidence interval and Hosmer-Lemeshow goodness-of-fit test.

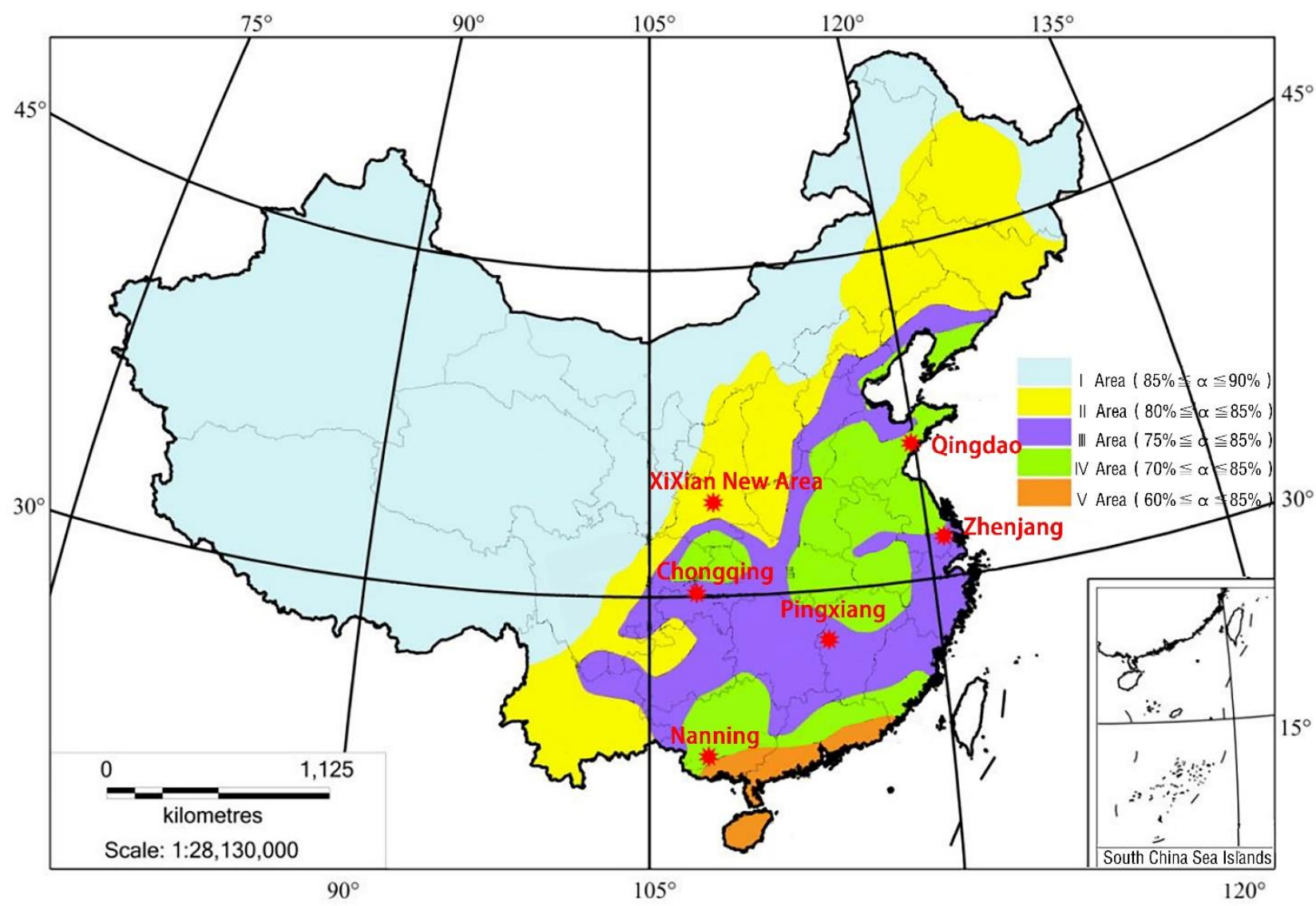

Figure 1. The location of six pilot sponge cities and five zones based on the 'annual rainfall control rates' $(\alpha)$ in mainland China (The figure is adapted from 'Sponge City Technical Guidelines' [28]).

\subsubsection{Multiordinal Logistic Regression}

The amount respondents are willing to pay took the form of an ordinal variable. Thus, a multiordinal logistic model in SPSS 24.0 was used to analyze the influencing factors for the amount respondents are willing to pay. The amount respondents are willing to pay was set as a dependent variable and the recognized correlated influencing factors were set as independent variables. The data was analyzed with a $95 \%$ confidence interval.

\section{Results}

\subsection{Profiles of Respondents' Sociodemographic Information and WTP}

Based on the bivariate correlation analysis between WTP and variables, the results showed that the places (shopping malls, local parks, or community-built GI) and the cities where the questionnaires were collected did not influence the WTP. The correlated variable information is shown in Table 1 with 1101 effective respondents (Figure 2). The male and female respondents were almost equal, with $52.9 \%$ female respondents. The age of the respondents followed a normal distribution. Respondents aged 26-35 (32.8\%) ranked in first place, followed by respondents aged $36-45(23.0 \%)$. Regarding education 
level, respondents with vocational-technical college degrees (24.7\%) or bachelor's degrees (29.2\%) accounted for the largest proportion. A total of 620 respondents or $56.3 \%$ of the total respondents reported family monthly income of 5001-10,000 RMB (approximately 793-1587 US dollars). Meanwhile, 56.8\% respondents replied that they knew of the concept of sponge cities, while $43.2 \%$ had never heard the concept. Approximately $67 \%$ expressed their WTP for the maintenance of sponge city GI facilities. Of the respondents, $13.7 \%$ would like to pay 1-5 RMB/month, $17 \%$ would like to pay about $6-10 \mathrm{RMB} /$ month (0.95-1.59 US dollars/month), and $17.8 \%$ would like to pay more than $20 \mathrm{RMB} /$ month (about $3.2 \mathrm{US}$ dollars/month).

Table 1. Profiles of respondents' demographic information and WTP.

\begin{tabular}{|c|c|c|c|}
\hline Items & Status & Frequency & Percentage \\
\hline \multirow{2}{*}{ Gender } & Female & 582 & $52.90 \%$ \\
\hline & Male & 519 & $47.10 \%$ \\
\hline \multirow{7}{*}{ Age } & 18 & 5 & $0.40 \%$ \\
\hline & $19-25$ & 147 & $13.40 \%$ \\
\hline & $26-35$ & 361 & $32.80 \%$ \\
\hline & $36-45$ & 253 & $23.00 \%$ \\
\hline & $46-55$ & 173 & $15.70 \%$ \\
\hline & $56-65$ & 76 & $6.90 \%$ \\
\hline & $>65$ & 86 & $7.80 \%$ \\
\hline \multirow{6}{*}{ Education level } & Primary school & 86 & $7.80 \%$ \\
\hline & Middle school & 180 & $16.30 \%$ \\
\hline & High school & 201 & $18.30 \%$ \\
\hline & Vocational-technical college & 272 & $24.70 \%$ \\
\hline & Bachelor's & 321 & $29.20 \%$ \\
\hline & Master's and PhD & 41 & $3.70 \%$ \\
\hline \multirow{6}{*}{$\begin{array}{l}\text { Family's monthly income } \\
\text { (RMB/month) }\end{array}$} & $1500-5000$ & 219 & $20 \%$ \\
\hline & $5001-10,000$ & 620 & $56.30 \%$ \\
\hline & $10,001-15,000$ & 154 & $14.00 \%$ \\
\hline & $15,001-20,000$ & 61 & $5.50 \%$ \\
\hline & $>20,000$ & 39 & $3.50 \%$ \\
\hline & Missing value & 8 & $0.70 \%$ \\
\hline \multirow{2}{*}{$\begin{array}{l}\text { Previous knowledge of } \\
\text { the sponge city concept }\end{array}$} & No & 476 & $43.20 \%$ \\
\hline & Yes & 625 & $56.80 \%$ \\
\hline \multirow{2}{*}{ Willingness to pay (WTP) } & No & 367 & $33.30 \%$ \\
\hline & Yes & 734 & $66.70 \%$ \\
\hline \multirow{9}{*}{$\begin{array}{l}\text { Amount willing to pay } \\
\text { (RMB/month) }\end{array}$} & Wouldn't like to pay & 367 & $33.30 \%$ \\
\hline & $1-5$ & 151 & $13.70 \%$ \\
\hline & $6-10$ & 187 & $17.00 \%$ \\
\hline & $11-15$ & 120 & $10.90 \%$ \\
\hline & $16-20$ & 80 & $7.30 \%$ \\
\hline & $21-30$ & 53 & $4.80 \%$ \\
\hline & $31-50$ & 70 & $6.40 \%$ \\
\hline & $51-100$ & 55 & $5.00 \%$ \\
\hline & $>100$ & 18 & $1.60 \%$ \\
\hline
\end{tabular}

(1 US dollar $\approx 6.3 \mathrm{RMB})$ 


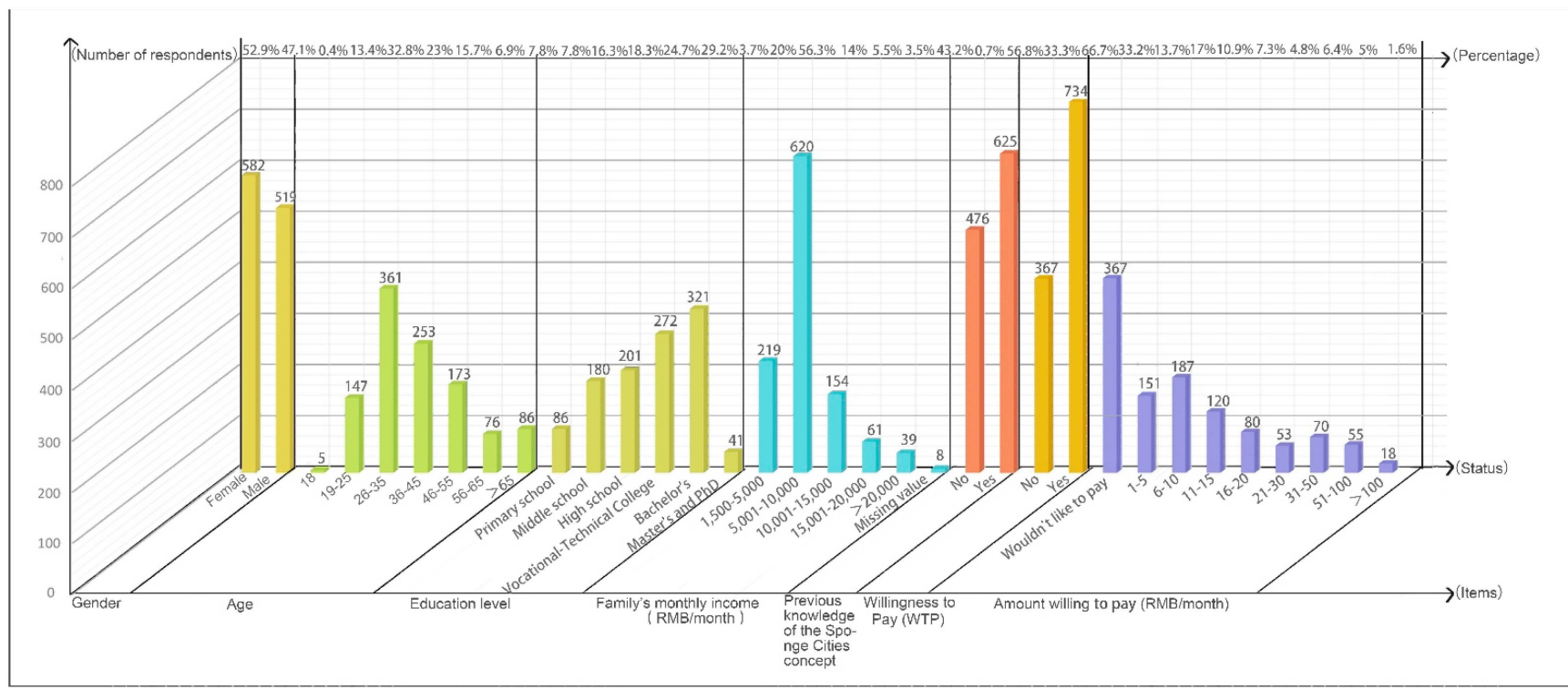

Figure 2. Profiles of respondents' demographic information and WTP.

\subsection{Factors Influencing Respondents' WTP}

The bivariate correlation analysis showed that gender, age, education level, family's monthly income, and previous knowledge of the sponge city concept influenced the respondents' WTP. Based on the binary logistic model, the variables age, education level, and previous knowledge of the sponge city concept significantly influenced the respondents' WTP. The results are shown in Table 2.

Table 2. Results of factors influencing respondents' WTP.

\begin{tabular}{|c|c|c|c|c|c|}
\hline Variables & B & Standard Error & Wald Statistics & Significance & EXP(B) \\
\hline Age & -0.20 & 0.006 & 12.919 & 0.000 & 0.980 \\
\hline Gender & 0.266 & 0.137 & 3.781 & 0.052 & 1.304 \\
\hline $\begin{array}{l}\text { Previous knowledge of the sponge } \\
\text { city concept }\end{array}$ & 0.291 & 0.139 & 4.368 & 0.037 & 1.337 \\
\hline Education level (Primary School) & & & 24.440 & 0.000 & \\
\hline Education level (Middle School) & 0.604 & 0.277 & 4.743 & 0.029 & 1.829 \\
\hline Education level (High School) & 0.502 & 0.284 & 3.122 & 0.077 & 1.652 \\
\hline $\begin{array}{l}\text { Education level (Vocational-Technical } \\
\text { College) }\end{array}$ & 0.660 & 0.289 & 5.231 & 0.022 & 1.935 \\
\hline Education level (Bachelor's) & 1.308 & 0.305 & 18.428 & 0.000 & 3.699 \\
\hline Education level (Master's and PhD) & 1.196 & 0.481 & 6.174 & 0.013 & 3.307 \\
\hline Constant & 0.513 & 0.394 & 1.689 & 0.194 & 1.670 \\
\hline
\end{tabular}

$B$ represents partial regression coefficients; EXP(B) represents odds ratio.

With an increase in the respondents' age, there was a decrease in WTP for the maintenance of GI facilities. The male respondents were more likely to pay for the maintenance of GI facilities, which was 1.304 times more than the female respondents, though there were more female respondents (52.9\%). If the respondents had previous knowledge of the sponge city concept, their WTP was 1.337 times higher than those who did not know the concept. Meanwhile, educational level also influenced the respondents' WTP significantly. The WTP of respondents who had received a bachelor's degree or postgraduate education were 3.669 and 3.307 times higher, separately, than those who had only graduated from primary school. 


\subsection{Factors Influencing Amount Respondents'Are Willing to Pay}

Based on the multiordinal logistic regression, the factors influencing the probability of the amount respondents are willing to pay were analyzed and the results are shown in Table 3. The variables in terms of gender and previous knowledge of the sponge city concept did not influence the probability of the amount respondents are willing to pay. The age of the respondents influenced the willing to pay amount significantly. In each level of willing to pay amount, the probability decreased with an increase in respondents age. Education level was another influencing factor for the probability of the willing to pay amount. Especially for the level of amount 16-20, 51-100, and $>100 \mathrm{RMB} / \mathrm{month}$, the higher the respondents' education level, the probability of the willing to pay amount was higher. In addition, for those who would like to pay more than $100 \mathrm{RMB} / \mathrm{month}$, the family's monthly income is a significant influencing factor (Table 3).

Table 3. Results of factors influencing the amount respondents are willing to pay.

\begin{tabular}{|c|c|c|c|c|c|c|}
\hline $\begin{array}{l}\text { Willing to Pay } \\
\text { Amount } \\
\text { (RMB/Month) }\end{array}$ & Factors & B & Standard Error & Wald Statistics & Significance & EXP(B) \\
\hline $6-10$ & Age & -0.22 & 0.009 & 5.759 & 0.016 & 0.978 \\
\hline $11-15$ & Age & -0.54 & 0.012 & 19.858 & 0.000 & 0.948 \\
\hline \multirow{3}{*}{$16-20$} & $\begin{array}{c}\text { Age } \\
\text { Education level (Middle School) } \\
\text { Education level (High School) }\end{array}$ & $\begin{array}{l}-0.048 \\
-3.939 \\
-2.723\end{array}$ & $\begin{array}{l}0.014 \\
1.323 \\
1.153\end{array}$ & $\begin{array}{l}11.318 \\
8.870 \\
5.578\end{array}$ & $\begin{array}{l}0.001 \\
0.003 \\
0.018\end{array}$ & $\begin{array}{l}0.953 \\
0.019 \\
0.066\end{array}$ \\
\hline & $\begin{array}{c}\text { Education level (Vocational-Technical } \\
\text { College) }\end{array}$ & -2.141 & 1.111 & 3.710 & 0.054 & 0.118 \\
\hline & $\begin{array}{c}\text { Education level (Bachelor's) } \\
\text { Education level (Master's and PhD) }\end{array}$ & $\begin{array}{c}-1.422 \\
0^{\mathrm{b}}\end{array}$ & 1.111 & 1.639 & 0.200 & 0.241 \\
\hline $21-30$ & Age & -0.050 & 0.017 & 9.062 & 0.003 & 0.951 \\
\hline $31-50$ & Age & -0.024 & 0.013 & 3.147 & 0.076 & 0.976 \\
\hline \multirow{3}{*}{$51-100$} & $\begin{array}{c}\text { Age } \\
\text { Education level (Middle School) } \\
\text { Education level (High School) }\end{array}$ & $\begin{array}{l}-0.084 \\
-2.142 \\
-2.358\end{array}$ & $\begin{array}{l}0.018 \\
1.211 \\
1.178\end{array}$ & $\begin{array}{l}21.684 \\
3.128 \\
4.009\end{array}$ & $\begin{array}{l}0.000 \\
0.077 \\
0.045\end{array}$ & $\begin{array}{l}0.919 \\
0.117 \\
0.095\end{array}$ \\
\hline & $\begin{array}{c}\text { Education level (Vocational-Technical } \\
\text { College) }\end{array}$ & -2.372 & 1.144 & 4.296 & 0.038 & 0.093 \\
\hline & $\begin{array}{c}\text { Education level (Bachelor's) } \\
\text { Education level (Master's and PhD) }\end{array}$ & $\begin{array}{c}-1.749 \\
0^{\mathrm{b}}\end{array}$ & 1.138 & 2.362 & 0.124 & 0.174 \\
\hline \multirow{3}{*}{$>100$} & $\begin{array}{c}\text { Age } \\
\text { Family month income }\end{array}$ & $\begin{array}{c}-0.072 \\
0.042\end{array}$ & $\begin{array}{l}0.026 \\
0.020\end{array}$ & $\begin{array}{l}7.512 \\
4.282\end{array}$ & $\begin{array}{l}0.006 \\
0.039\end{array}$ & $\begin{array}{l}0.930 \\
1.043\end{array}$ \\
\hline & $\begin{array}{c}\text { Education level (Vocational-Technical } \\
\text { College) }\end{array}$ & -2.970 & 1.262 & 5.533 & 0.019 & 0.051 \\
\hline & $\begin{array}{c}\text { Education level (Bachelor's) } \\
\text { Education level (Master's and PhD) }\end{array}$ & $\begin{array}{l}-2.867 \\
0^{b}\end{array}$ & 1.272 & 5.081 & 0.024 & 0.057 \\
\hline
\end{tabular}

${ }^{a}$ reference category: $<5 \mathrm{RMB} /$ month. $^{\mathrm{b}}$ means the education level (Master's and $\mathrm{PhD}$ ) is the reference category.

\section{Discussion}

\subsection{The Influence of Demographic Information}

\subsubsection{Age}

As shown in Section 3.2, age was a significant determinant for the probability of WTP for the maintenance of the sponge cities' GI facilities. The respondents' WTP decreased with increasing age, while previous studies have reported similar results showing age having a significant negative impact on respondents' WTP $[21,37,42,49,50]$. In addition, we found that age can also influence the willing to pay amount, where an increase of age decreases the probability of the willing to pay amount. This is in line with other studies $[37,40,42,50]$. The Chinese government announced the old residential areas would be rebuilt in the outline of the 14th Five-Year Plan (2021-2025), providing a chance to incorporate GI during the rebuilding process. In many pilot sponge cities, the construction of GI facilities was applied in connection with the reconstruction of old residential areas, which usually housed elderly people. Thus, funding GI maintenance via a fee in old 
residential areas is likely to meet challenges, as the older population, according to our findings, are generally less likely to pay it.

\subsubsection{Gender}

Normally, gender is an influencing factor for public perceptions, acceptance of certain issues, and WTP $[40,51]$. Our study showed that male respondents were more likely to pay for the maintenance of the sponge cities' GI facilities than females. Similarly, a mail survey of consumers in Northern Virginia and Washington, D.C. looking at improved drinking water quality and infrastructure showed that males are more likely to be willing to pay to support it [21]. It was also reported that male respondents were more likely to pay than their female counterparts to improve municipal water in southeast Anatolia, Turkey [52].

However, the influence of gender can vary from case to case. A survey of professionals involved in sponge city implementation in South China showed that female professionals were more supportive of the sponge city implementation than male professionals [53]. A study regarding households' WTP for maintaining and improving water supplies in Mexico City also reported that female respondents were, in general, more likely to respond positively [54]. In addition, a contingent valuation study about WTP for sustainable drainage systems in Hong Kong showed no significant difference in terms of respondents' genders [50]. Regarding the amount respondents are willing to pay, gender was not a significant influencing factor in our study. This result is in accordance with findings by Chui et al. (2016) [50].

\subsubsection{Education Level}

Education level was shown to have a significant influence on the respondents' WTP in this study. This bears similarities with other studies, which have also reported that the probability of WTP increases with an increase in level of education [1,21,40,45,48,55,56]. Ding et al., (2019) conducted a similar contingent-valuation investigation looking at the WTP of life-cycle maintenance of sponge city facilities in three pilot cities, Shenzhen, Zhenjiang, and Xi'an (two of them are case cities used in our study) in China with 481 respondents [42]. However, they reported that education level had no relationship with WTP. Their result was opposite with our findings and other studies $[1,21,40,45,48,55,56]$. In addition, Ding et al., (2019) found that the level of education and family income had no significant effect on the amount respondents are willing to pay. However, based on our findings, as shown in Section 3.3, education level had a significant positive effect on the amount respondents are willing to pay. Ding et al., (2019) explained that their distinct results might be due to the lack of respondents with low-level education and household income in their study. Thus, the general level of educational must be regarded as a significant factor, also in relation to the potential implementation of fees for GI maintenance.

\subsection{The Influence of Perceptions on the Sponge Cities Concept}

In a previous study, a survey conducted by Tanellari et al. (2017) showed that consumers' risk perceptions can affect their WTP for water quality improvement programs [21]. A study of the actual behaviors and attitudes of 71 relevant stakeholders towards water related GI in three Italian regions and one French region in the northwestern Mediterranean showed that the main limitation to water related GI adoption was due to an absence of knowledge of the GI solutions [5]. Similarly, Xie et al., (2020) found that the recognition of the sponge city concept as a sustainable way for stormwater management is important for achieving professional advocacy for the sponge cities' policies and their implementation [53]. This is in accordance with our results shown in Section 3.2; if the respondents had previous knowledge of the concept of sponge cities, they were more likely to be willing to pay for the maintenance of GI facilities. Thus, information campaigns or education programs regarding the sponge city concept for professionals and the public are of significance for increasing the WTP for GI facility implementation and maintenance $[1,50,53,56]$. However, as shown in Section 3.3, the amount respondents are willing to pay was not 
significantly influenced by their perceptions of the sponge city concept. Thus, the public was willing to pay for the maintenance, but the amount respondents are willing to pay may not cover the actual maintenance costs.

\subsection{Potentials to Improve the Maintenance Situation of GI Facilities}

Stormwater fees are important to maintain the public stormwater system, and it is a way for communities to share the cost of a public service to decrease the negative impacts of urbanization and climate change [30]. As mentioned above, most of the respondents would like to pay a maintenance fee for GI, but the amount of payment may not cover the actual maintenance costs. A study in Pakistan showed that cash support programs can help to increase the willingness to participate in environmental services at the household and community levels [36]. Meanwhile, researchers reported that the maintenance of public and private urban GI can provide significant employment [57]. Therefore, government financial support combined with residential stormwater fees might be a potential solution for the maintenance of GI in existing and future sponge city initiatives in China. In addition, due to COVID-19, citizens were confined to their dwellings or communities; a survey of citizens living in 35 different countries showed that respondents missed having a garden during the confinement and the outdoor space value increased after the confinement, and the WTP for an accessible green roof increased [35]. This may increase the WTP for GI maintenance. In our study, we did not consider the influence of COVID-19, but in future studies, the influence of COVID-19 on the WTP for GI or GI maintenance should be considered.

\section{Conclusions}

In this paper, we aimed to explore whether the residents of pilot sponge cities are willing to pay stormwater fees to fund the maintenance of GI facilities. We found that most of the respondents had a positive attitude towards paying for maintenance activities, and $67 \%$ of the respondents were actually willing to pay. Of the respondents, $17 \%$ would like to pay about 6-10 RMB/month (0.95-1.59 US dollars per month), and $17.8 \%$ would like to pay more than $20 \mathrm{RMB} /$ month (about 3.2 US dollar per month). Therefore, decision makers can view stormwater fees as one of the maintenance funding sources for future sponge city maintenance programs.

Respondents with a higher educational level were more likely to pay, while the age of respondents had a negative impact on their WTP. The findings are in accordance with most of the previous contingent-valuation studies. This indicates that maintenance funding would still be a challenge in the residential areas with mostly elderly residents.

As knowledge of the concept of the sponge cities can increase the respondents' WTP, more public education and information campaigns on the importance of maintenance for the sponge cities' GI facilities would be helpful. In the future, more research on public contingent valuation of stormwater fees as maintenance funding should be conducted in different cities, as well as adapted to other parts of the world for comparison.

There exists some limitations in the study. Although we selected three kinds of places to collect questionnaires, the number of questionnaires collected from the three places were not equal. Due to COVID-19, the questionnaires collected from the communities having built GI facilities were comparatively less. In addition, the respondents who rent apartments were not included in this study. In the future, it would be interesting to understand their WTP for GI maintenance.

Author Contributions: X.-J.Q. wrote the original draft and revised the manuscript; T.B.R. revised the manuscript. All authors have read and agreed to the published version of the manuscript.

Funding: This research was funded by [Northwest A\&F University PhD Start Grant] grant number Z1090220176] and The APC was funded by [Swedish University of Agricultural Sciences].

Institutional Review Board Statement: Not applicable.

Informed Consent Statement: Informed consent was obtained from all subjects involved in the study. 


\section{Data Availability Statement: Not applicable.}

Acknowledgments: We would like to thank the students who helped to collect the questionnaires and the postgraduate, Jin, Yanju, who helped to revise the figures. We also would like to thank the three reviewers and the academic editor.

Conflicts of Interest: The authors declare no conflict of interest.

\section{References}

1. Meng, T.; Hsu, D. Stated preferences for smart green infrastructure in stormwater management. Landsc. Urban Plan. 2019, 187, 1-10. [CrossRef]

2. Moulds, S.; Buytaert, W.; Templeton, M.R.; Kanu, I. Modeling the Impacts of Urban Flood Risk Management on Social Inequality. Water Resour. Res. 2021, 57, e2020WR029024. [CrossRef]

3. Ureta, J.; Motallebi, M.; Vassalos, M.; Alhassan, M.; Ureta, J.C. Valuing stakeholder preferences for environmental benefits of stormwater ponds: Evidence from choice experiment. J. Environ. Manag. 2021, 293, 112828. [CrossRef] [PubMed]

4. $\quad$ Pauleit, S.; Zölch, T.; Hansen, R.; Randrup, T.B.; van den Bosch, C.K. Nature-Based Solutions and Climate Change-Four Shades of Green. In Nature-Based Solutions to Climate Change Adaptation in Urban Areas; Springer: Cham, Switzerland, 2017 ; pp. 29-49.

5. Piacentini, S.M.; Rossetto, R. Attitude and Actual Behaviour towards Water-Related Green Infrastructures and Sustainable Drainage Systems in Four North-Western Mediterranean Regions of Italy and France. Water 2020, 12, 1474. [CrossRef]

6. Shafique, M.; Xue, X.; Luo, X. An overview of carbon sequestration of green roofs in urban areas. Urban For. Urban Green. 2020, 47, 126515. [CrossRef]

7. Benedict, M.A. Green Infrastructure Linking Landscapes and Communities; McMahon, E., Ed.; Island Press: Washington, DC, USA, 2006.

8. Turkelboom, F.; Demeyer, R.; Vranken, L.; De Becker, P.; Raymaekers, F.; De Smet, L. How does a nature-based solution for flood control compare to a technical solution? Case study evidence from Belgium. AMBIO 2021, 50, 1431-1445. [CrossRef]

9. Chen, V.; Brenes JR, B.; Chapa, F.; Hack, J. Development and modelling of realistic retrofitted Nature-based Solution scenarios to reduce flood occurrence at the catchment scale. AMBIO 2021, 50, 1462-1476. [CrossRef]

10. Shafique, M.; Kim, R. Recent Progress in Low-Impact Development in South Korea: Water-Management Policies, Challenges and Opportunities. Water 2018, 10, 435. [CrossRef]

11. McFarland, A.R.; Larsen, L.; Yeshitela, K.; Engida, A.N.; Love, N.G. Guide for using green infrastructure in urban environments for stormwater management. Environ. Sci.-Water Res. Technol. 2019, 5, 643-659. [CrossRef]

12. Rodak, C.M.; Moore, T.L.; David, R.; Jayakaran, A.D.; Vogel, J.R. Urban stormwater characterization, control, and treatment. Water Environ. Res. 2020, 92, 1552-1586. [CrossRef]

13. Stessens, P.; Canters, F.; Huysmans, M.; Khan, A.Z. Urban green space qualities: An integrated approach towards GIS-based assessment reflecting user perception. Land Use Policy 2020, 91, 104319. [CrossRef]

14. Dempsey, N.; Smith, H.; Burton, M. (Eds.) Place-Keeping: Open Space Management in Practice; Routledge: New York, NY, USA, 2014.

15. Qiao, X.J.; Liao, K.H.; Randrup, T.B. Sustainable stormwater management: A qualitative case study of the Sponge Cities initiative in China. Sustain. Cities Soc. 2020, 53, 101963. [CrossRef]

16. Drake, J.; Guo, Y. Maintenance of wet stormwater ponds in Ontario. Can. Water Resour. J. 2008, 33, 351-368. [CrossRef]

17. Asleson, B.C.; Nestingen, R.S.; Gulliver, J.S.; Hozalski, R.M.; Nieber, J.L. Performance assessment of rain gardens. J. Am. Water Resour. Assoc. 2009, 45, 1019-1031. [CrossRef]

18. Li, H. Green Infrastructure for Highway Stormwater Management: Field Investigation for Future Design, Maintenance, and Management Needs. J. Infrastruct. Syst. 2015, 21, 05015001. [CrossRef]

19. Reyes NJ, D.G.; Geronimo FK, F.; Choi, H.S.; Kim, L.H. Performance assessment of an urban stormwater infiltration trench considering facility maintenance. J. Wetl. Res. 2018, 20, 424-431.

20. Pour, S.H.; Abd Wahab, A.K.; Shahid, S.; Asaduzzaman, M.; Dewan, A. Low impact development techniques to mitigate the impacts of climate-change-induced urban floods: Current trends, issues and challenges. Sustain. Cities Soc. 2020, 62, 102373. [CrossRef]

21. Tanellari, E.; Bosch, D.; Boyle, K.; Mykerezi, E. On consumers' attitudes and willingness to pay for improved drinking water quality and infrastructure. Water Resour. Res. 2015, 51, 47-57. [CrossRef]

22. Gao, Y.; Babin, N.; Turner, A.J.; Hoffa, C.R.; Peel, S.; Prokopy, L.S. Understanding urban-suburban adoption and maintenance of rain barrels. Landsc. Urban Plan. 2016, 153, 99-110. [CrossRef]

23. Shafique, M.; Kim, R.; Rafiq, M. Green roof benefits, opportunities and challenges-A review. Renew. Sustain. Energy Rev. 2018, 90, 757-773. [CrossRef]

24. Bixler, T.S.; Houle, J.; Ballestero, T.; Mo, W. A dynamic life cycle assessment of green infrastructures. Sci. Total Environ. 2019, 692, 1146-1154. [CrossRef] [PubMed]

25. Bixler, T.S.; Houle, J.; Ballestero, T.P.; Mo, W. A spatial life cycle cost assessment of stormwater management systems. Sci. Total Environ. 2020, 728, 138787. [CrossRef] [PubMed] 
26. O'Donnell, E.C.; Thorne, C.R.; Yeakley, J.A.; Chan, F.K.S. Sustainable flood risk and stormwater management in Blue-Green Cities; an Interdisciplinary case study in Portland, Oregon. J. Am. Water Resour. Assoc. 2020, 56, 757-775. [CrossRef]

27. Qiao, X.J.; Liu, L.; Kristoffersson, A.; Randrup, T.B. Governance factors of sustainable stormwater management: A study of case cities in China and Sweden. J. Environ. Manag. 2019, 248, 109249. [CrossRef] [PubMed]

28. MHURD. Sponge City Technical Guideline-Low Impact Development. 2014. Available online: https://www.mohurd.gov.cn/ gongkai/fdzdgknr/tzgg/201411/20141103_219465.html (accessed on 7 January 2022).

29. Johns, C.M. Understanding barriers to green infrastructure policy and stormwater management in the City of Toronto: A shift from grey to green or policy layering and conversion? J. Environ. Plan. Manag. 2019, 62, 1377-1401. [CrossRef]

30. Tasca, F.A.; Finotti, A.R.; Goerl, R.F. A stormwater user fee model for operations and maintenance in small cities. Water Sci. Technol. 2019, 79, 278-290. [CrossRef] [PubMed]

31. Cousins, J.J. Infrastructure and institutions: Stakeholder perspectives of stormwater governance in Chicago. Cities 2017, 66, 44-52 [CrossRef]

32. William, R.; Garg, J.; Stillwell, A.S. A game theory analysis of green infrastructure stormwater management policies. Water Resour. Res. 2017, 53, 8003-8019. [CrossRef]

33. Zhang, D.; Gersberg, R.M.; Ng, W.J.; Tan, S.K. Conventional and decentralized urban stormwater management: A comparison through case studies of Singapore and Berlin, Germany. Urban Water J. 2017, 14, 113-124. [CrossRef]

34. Adegun, O. Developing Green Infrastructure in a Johannesburg Informal Settlement: Investigating Residents' Willingness to Pay Procedia Eng. 2017, 198, 176-186. [CrossRef]

35. Manso, M.; Sousa, V.; Silva, C.M.; Cruz, C.O. The role of green roofs in post COVID-19 confinement: An analysis of willingness to pay. J. Build. Eng. 2022, 44, 103388. [CrossRef]

36. Nawaz, S.; Gul, F. Cash transfer program and willingness to pay for environmental services among the ultra-poor in Pakistan. Environ. Sci. Pollut. Res. 2022, 1-16. [CrossRef] [PubMed]

37. Sabyrbekov, R.; Dallimer, M.; Navrud, S. Nature affinity and willingness to pay for urban green spaces in a developing country. Landsc. Urban Plan. 2020, 194, 103700. [CrossRef]

38. Li, Q.; Wang, F.; Yu, Y.; Huang, Z.; Li, M.; Guan, Y. Comprehensive performance evaluation of LID practices for the sponge city construction: A case study in Guangxi, China. J. Environ. Manag. 2019, 231, 10-20. [CrossRef]

39. Wang, Y.; Liu, X.; Huang, M.; Zuo, J.; Rameezdeen, R. Received vs. given: Willingness to pay for sponge city program from a perceived value perspective. J. Clean. Prod. 2020, 256, 120479. [CrossRef]

40. Wang, Y.; Sun, M.; Song, B. Public perceptions of and willingness to pay for sponge city initiatives in China. Resour. Conserv. Recycl. 2017, 122, 11-20. [CrossRef]

41. Zhang, L.; Sun, X.; Xue, H. Identifying critical risks in Sponge City PPP projects using DEMATEL method: A case study of China. J. Clean. Prod. 2019, 226, 949-958. [CrossRef]

42. Ding, L.; Ren, X.; Gu, R.; Che, Y. Implementation of the "sponge city" development plan in China: An evaluation of public willingness to pay for the life-cycle maintenance of its facilities. Cities 2019, 93, 13-30. [CrossRef]

43. The Chinese Central Government. The Outline of the 14th Five-Year Plan (2021-2025) for National Economic and Social Development and the Long-Range Objectives through the Year 2035. 2021. Available online: https://www.12371.cn/special/ ssw2035/ (accessed on 7 January 2022).

44. Mullen, J.D.; Calhoun, K.C.; Colson, G.J. Preferences for policy attributes and willingness to pay for water quality improvements under uncertainty. Water Resour. Res. 2017, 53, 2627-2642. [CrossRef]

45. Ali MA, S.; Khan, S.U.; Khan, A.; Khan, A.A.; Zhao, M. Ranking of ecosystem services on the basis of willingness to pay: Monetary assessment of a subset of ecosystem services in the Heihe River basin. Sci. Total Environ. 2020, 734, 139447. [CrossRef]

46. Deely, J.; Hynes, S. Blue-green or grey, how much is the public willing to pay? Landsc. Urban Plan. 2020, 203, 103909. [CrossRef]

47. Lehtoranta, V.; Louhi, P. Does conservation in Natura 2000 areas promote water quality improvement? Findings from a contingent valuation study on environmental benefits and residents' preferences. Environ. Sci. Policy 2021, 124, 226-234. [CrossRef]

48. Brent, D.A.; Gangadharan, L.; Lassiter, A.; Leroux, A.; Raschky, P.A. Valuing environmental services provided by local stormwatermanagement. Water Resour. Res. 2017, 23, 4907-4921. [CrossRef]

49. Vasquez, W.F. Willingness to pay and willingness to work for improvements of municipal and community-managed water services. Water Resour. Res. 2014, 50, 8002-8014. [CrossRef]

50. Chui, T.F.M.; Ngai, W.Y. Willingness to pay for sustainable drainage systems in a highly urbanised city: A contingent valuation study in Hong Kong. Water Environ. J. 2016, 30, 62-69. [CrossRef]

51. Robson, E.; van Kerkhoff, L.; Cork, S. Understanding citizen perceptions of the Eastern Hills of Bogota: A participatory place-based ecosystem service assessment. Urban Ecosyst. 2019, 22, 19-35. [CrossRef]

52. Bilgic, A. Measuring willingness to pay to improve municipal water in southeast Anatolia, Turkey. Water Resour. Res. 2010, 46. [CrossRef]

53. Xie, X.; Qin, S.; Gou, Z.; Yi, M. Engaging professionals in urban stormwater management: The case of China's Sponge City. Build. Res. Inf. 2020, 48, 719-730. [CrossRef]

54. Soto Montes de Oca, G.; Bateman, I.J. Scope sensitivity in households' willingness to pay for maintained and improved water supplies in a developing world urban area: Investigating the influence of baseline supply quality and income distribution upon stated preferences in Mexico City. Water Resour. Res. 2006, 42, 1-15. [CrossRef] 
55. Exposito, A.; Espinosa, M.; Villa-Damas, A. Valuing Visitor Willingness to Pay for Urban Green Space Conservation: Case of Maria Luisa Park in Seville, Spain. J. Urban Plan. Dev. 2021, 147, 05021020. [CrossRef]

56. Rashid, M.; Pandit, D. Rural communities' perception of and willingness to pay for wastewater and stormwater management infrastructure in Bihar, India. J. Water Sanit. Hyg. Dev. 2020, 10, 36-47. [CrossRef]

57. King, A.; Shackleton, C.M. Maintenance of public and private urban green infrastructure provides significant employment in Eastern Cape towns, South Africa. Urban For. Urban Green. 2020, 54, 126740. [CrossRef] 